\title{
OPTICAL RESOLUTION OF KEY COMPOUNDS OF PROSTAGLANDIN SYNTHESIS
} AND RELATED COMPOUNDS

\author{
Fumio TODA ${ }^{*}$ and Koichi TANAKA \\ Department of Industrial Chemistry, Faculty of Engineering, \\ Ehime University, Matsuyama 790
}

Hundred per cent optically pure bicyclic lactones and bicyclic ketones were easily obtained by complexation method with optically active 1,6-bis(2-chlorophenyl)-1,6-diphenylhexa-2,4diyne-1,6-diol.

Optically active bicyclo[3.2.0] hept-2-en-6-one $(\underset{\sim}{1})$ and 6-oxabicyclo [3.3.0]oct-2-en-7-one (2) are key compounds of the preparation of various prostaglandins via the Corey lactone $\left({ }^{3}\right)$. The most successful preparative method of the optically pure 2 is a biological resolution of $\underset{\sim}{1}$ followed by a Baeyer-Villiger oxidation to 2 . Since one enantiomer of $\frac{1}{2}$ is reduced by a yeast to alcohol, $\frac{1}{2}$ can be resolved.

We found that 2 can easily be resolved by complexation method with an artificial optically active compound, 1,6-bis(2-chlorophenyl)-1,6-diphenylhexa-2,4-diyne1,6-diol ( $\underbrace{4})$. It was also disclosed that the method is applicable to obtain 1008 optically pure 2-oxabicyclo[3.3.0]octan-3-one $(\underset{2}{5}), 7$-oxabicyclo[4.3.0]non-2-

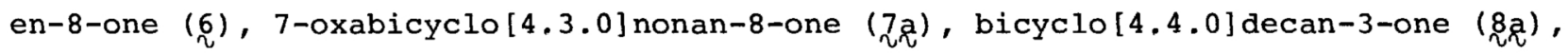
and 6-methylbicycl $[4.4 .0]$ dec-l-en-3-one ( ( $^{\mathrm{b}}$ ).

optically pure $\underset{2}{6}$ is an important key compound for the synthesis of 11-desoxyprostaglandins. Optically pure $\underset{\mathrm{C}}{9 \mathrm{~b}}$ is also an useful starting material for the preparation of various physiologically active compounds.

When a solution of $(-)-\underset{\sim}{4}(10.0 \mathrm{~g}, 20.7 \mathrm{mmol})$ and (I) $-\underset{\sim}{2}(10.3 \mathrm{~g}, 82.8 \mathrm{mmol})$ in 2:1 ether-light petroleum (45 ml) was kept at room temperature for $6 \mathrm{~h}, \mathrm{a} 1: 2$ complex of $(-)--_{2}^{4}$ and $(+)-2(15.0 \mathrm{~g}, 998)$ was obtained, which upon distillation gave $8.5 \%$ ee $(+)-2$ (5.0 g, 97\%). Ten recrystallizations of the $1: 2$ complex of $(-)-\stackrel{4}{\sim}$ and 8.58 ee $(+)-2(15.0 \mathrm{~g})$ from ether $(40 \mathrm{ml}$ each) gave the complex of 


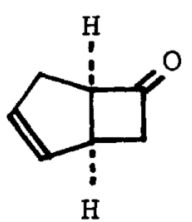

$\frac{1}{2}$<smiles>OC(C#CC#CC(O)(c1ccccc1)c1ccccc1Cl)(c1ccccc1)c1ccccc1Cl</smiles>

$\stackrel{4}{2}$

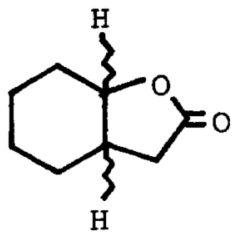

7

a: cis

b: trans

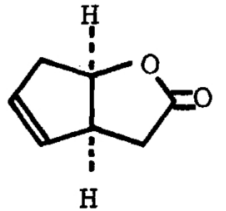

2<smiles>O=CC1C([18OH])[CH]C[C@H]2OC(=O)C[C@@H]12</smiles>

3<smiles>O=C(O)CC1CCCC1</smiles>

ᄂ<smiles>O=C1C[C@@H]2C=CC(CCC2)O1</smiles>

$\stackrel{6}{2}$<smiles>[H][Z]1([H])CCCCC12CCC(=O)CC2([2H])[2H]</smiles>

$\stackrel{8}{2}$

a: cis

b: trans<smiles>[R]C12CCCCC1=CC(=O)CC2</smiles>

?

a: $\mathrm{R}=\mathrm{H}$

$\mathrm{b}: \mathrm{R}=\mathrm{Me}$

C : $\mathrm{R}=\mathrm{E} \mathrm{t}$

$(-)-\frac{4}{2}$ and $100 \%$ ee $(+)-2(1.67 \mathrm{~g}, 11 \%)$ as colorless needles, mp 118-120 ${ }^{\circ} \mathrm{C},[\alpha] \mathrm{D}$ $\left.-55.1^{\circ}, 6\right)$ which upon distillation gave $100 \%$ ee $(+)-2(0.52 \mathrm{~g}, 10 \%),[\alpha]_{D}+110^{\circ}$. However, optical resolution of $d$ by this complexation method is not successful. For example, when a solution of $(-)-\frac{4}{2}(10.0 \mathrm{~g}, 20.7 \mathrm{mmol})$ and $( \pm)-\frac{1}{2}(8.94 \mathrm{~g}, 82.8$ mmol) in 1:5 ether-light petroleum ( $12 \mathrm{ml}$ ) was kept at room temperature for $6 \mathrm{~h}$, a $1: 2$ complex of $(-)-\frac{4}{2}$ and $(-)-\frac{1}{2}(10.1 \mathrm{~g}, 70 \%)$ was obtained as colorless needles, which upon distillation gave $8.3 \%$ ee $(-)-\frac{1}{2}(3.08 \mathrm{~g}, 69 \%),[\alpha]_{D}-5.2^{\circ}$. BaeyerVilliger oxidation of the $(-)-\frac{1}{2}$ gave $8.3 \%$ ee $(+)-\frac{2}{2}$. However, since recrystallization of the complex of $(-)-\frac{4}{2}$ and $(-)-\frac{1}{2}$ is very difficult, we could not get optically pure $(-)-l$. Nonetheless, dihydro derivative of $2 \underset{2}{(5)}$ was easily resolved by the method. Four recrystallizations from 1:1 ether-light petroleum $(20 \mathrm{ml}$ each) of the 
1:2 complex of $(-)-\underset{\sim}{4}$ and $20 \%$ ee $(+)-25(5.4 \mathrm{~g})$ obtained in $75 \%$ yield by keeping a solution of $(-)-\underset{\sim}{4}(5.1 \mathrm{~g}, 10.6 \mathrm{mmol})$ and $5(5.34 \mathrm{~g}, 42.4 \mathrm{mmol})$ in $1: 1$ ether-light petroleum at room temperature for $6 \mathrm{~h}$, gave a $1: 2$ complex of $(-)-\underset{\sim}{4}$ and $100 \%$ ee (+)${ }_{2}^{5}(0.85 \mathrm{~g}, 11 \%)$ as colorless prisms, mp 95-96 ${ }^{\circ} \mathrm{C},[\alpha]_{\mathrm{D}}-81.0^{\circ}$, which upon distillation gave $100 \%$ ee $(+)-\underset{\sim}{5}(0.27 \mathrm{~g}, 10 \%),[\alpha]_{\mathrm{D}}+13.3^{\circ}$. The $[\alpha]_{\mathrm{D}}$ value was identical to that of hydrogenation product of $100 \%$ ee $(+)-2$.

Optical resolutions of $\underset{\sim}{6}$ and $7 d$ were also very successful. Two recrystallizations from 1:1 ether-light petroleum $(10 \mathrm{ml}$ each) of the $1: 2$ complex of $(-)-\underset{\sim}{4}$ and $(+)-6(2.0 \mathrm{~g})$ obtained in 478 yield by keeping a solution of $(-)-\frac{4}{\tau}(2.7 \mathrm{~g}, 5.6$ mmol) and $\oint(3.1 \mathrm{~g} 22.5 \mathrm{mmol})$ in $1: 1$ ether-light petroleum for $6 \mathrm{~h}$, gave a $1: 2$ complex of $(-)-\underset{\sim}{4}$ and $100 \%$ ee $(+)-\underset{\sim}{6}(0.55 \mathrm{~g}, 13 \%)$ as colorless needles, mp 95-97 ${ }^{\circ} \mathrm{C}$, ${ }^{[\alpha]_{D}}-72.6^{\circ}\left(\mathrm{CHCl}_{3}\right)$. Three recrystallizations from 2:1 ether-light petroleum (30 ml each) of the $1: 2$ complex of $(-)-\underset{2}{4}$ and $(+)-7 \mathrm{a}(9.7 \mathrm{~g})$ obtained in $88 \%$ yield by keeping a solution of $(-)-\underset{\sim}{4}(7.0 \mathrm{~g}, 14.5 \mathrm{mmol})$ and $7 \mathrm{a}(8.1 \mathrm{~g}, 58.0 \mathrm{mmol})$ in $1: 1$ ether-light petroleum $(40 \mathrm{ml})$ for $6 \mathrm{~h}$, gave a $1: 2 \mathrm{complex}(-)-\underset{\sim}{\sim}$ and $(+)-7 \mathrm{q}(3.65 \mathrm{~g}$, $338)$ as colorless prisms, mp 103-105 ${ }^{\circ} \mathrm{C},[\alpha]_{\mathrm{D}}-61.1^{\circ}$, which upon distillation gave $100 \%$ ee $(+)-\ddot{j}{ }_{0}(1.3 \mathrm{~g}, 32 \%),[\alpha]_{\mathrm{D}}+50.3^{\circ}\left(\mathrm{CHCl}_{3}\right)$. The $[\alpha]_{\mathrm{D}}$ value was identical to that of hydrogenation product of $100 \%$ ee $(+)-\underset{2}{6}$. However, the $[\alpha]_{D}$ value of $100 \%$ ee $(+)-7 a$ was higher than that $\left([\alpha]_{D}+41.9^{\circ}\left(\mathrm{CHCl}_{3}\right)\right)$ of the sample resolved previously.

It is interesting that the trans-isomer of $7 \mathrm{~d}(\mathrm{Zk})$ does not form complex with (-) -4 . Shape of molecule might be important for the formation of complex. Nonplanar molecule such as $\downarrow, 2, j, \xi$, or $7 k$ rather than planar one such as $7 k$ would be convenient for the formation of complex. This is well supported by an efficient resolution of $8 \mathrm{a}$ by the complexation method and by no complex formation of $8 \mathrm{k}$. Two recrystallizations from 1:l ether-light petroleum $(20 \mathrm{ml}$ each) of the $1: 2 \mathrm{complex}$ of (-) $-\underset{\sim}{4}$ and $(-)-8 \mathrm{~d}(4.4 \mathrm{~g})$ obtained in $54 \%$ yield by keeping a solution of $(-)-4$ $(5.0 \mathrm{~g}, 10.4 \mathrm{mmol})$ and $8 \mathrm{~g}(6.32 \mathrm{~g}, 41.6 \mathrm{mmol})$ in $1: 1$ ether-light petroleum (20 $\mathrm{ml})$ for $6 \mathrm{~h}$, gave a $1: 2$ complex of $(-)-\frac{4}{\sim}$ and $100 \%$ ee $(-)-8 \mathrm{~d}(1.8 \mathrm{~g}, 22 \%)$ as colorless needles, mp $118-112{ }^{\circ} \mathrm{C},[a]_{D}-92.3^{\circ}$, which upon distillation gave $100 \%$ ee (-) - $8 \mathrm{q}$ $(0.66 \mathrm{~g}, 208),[\alpha]_{D}-3.9^{\circ}$.

It is also interesting that $2 \mathrm{~d}$ is resolved efficiently, even though neither $2 \mathrm{~d}$ nor $2 \mathbb{E}$ forms complex with $(-)-\frac{4}{2}$. For example, two recrystallizations from $1: 1$ ether-light petroleum $(50 \mathrm{ml}$ each) of the $1: 2$ complex $(5.4 \mathrm{~g})$ obtained in $63 \%$ yield by keeping a solution of $(-)-\frac{4}{2}(5.1 \mathrm{~g}, 10.6 \mathrm{mmol})$ and $2 \mathrm{k}(7.0 \mathrm{~g}, 42.7 \mathrm{mmol})$ in $1: 2$ 
ether-light petroleum $(15 \mathrm{ml})$ for $6 \mathrm{~h}$, gave a $1: 2$ complex of $(-)-\frac{4}{2}$ and $100 \%$ ee $(+)-$ $2 \mathrm{l}(2.1 \mathrm{~g}, 248)$ as colorless prisms, mp $122-123^{\circ} \mathrm{C},[\alpha]_{\mathrm{D}}+15.6^{\circ}$, which upon distillation gave $100 \%$ ee $(+)-2 k(0.8 \mathrm{~g}, 23 \%),[\alpha]_{D}+219^{\circ}$. These results show that $(-)-$ 4 can recognize not only the chirality of $2 k$ but also whether the substituent $R$ of 2 is larger or smaller than Me.

The authors thank Dr. Roger F. Newton of the Glaxo Group Research Ltd. for a supply of the sample of $l$. Financial support from the Ministry of Education, Science and Culture through a Grant-in-Aid for Special Project Research (No. 59212030 ) is gratefully acknowledged.

References

1) R. F. Newton, J. Paton, D. P. Reynolds, S. Young, and S. M. Roberts, J. Chem. Soc., Chem. Commun., 1979, 908 .

2) F. Toda, K. Tanaka, T. Omata, K. Nakamura, and T. Öshima, J. Am. Chem. Soc., 105,5151 (1983).

3) E. J, Corey and T, Ravindranathan, Tetrahedron Lett., 1971, 4753.

4) All distillations were carried out with using Kugelrohr apparatus in vacuo.

5) Hundred per cent optical purity of 2 was determined by refering its reported

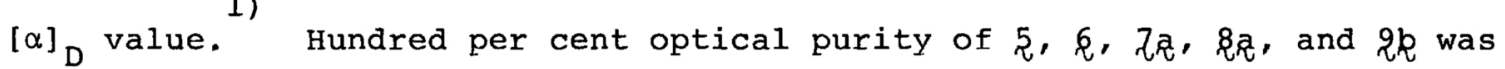
determined by no change of their $[\alpha]_{D}$ values on further resolution. Authentic samples of the $100 \%$ ee $\left\{\right.$ and $Z_{2}$ were also prepared by hydrogenation of the $100 \%$ ee 2 and $\ell$, respectively.

6) All the $[\alpha]_{D}$ values were measured at a concentration of $c 0.1$, in $\mathrm{MeOH}$ at $20{ }^{\circ} \mathrm{C}$ unless otherwise stated. All yields of the optically resolved compounds were based on the theoretical amount of the optical isomer contained in the initial (士) -compound.

7) W. H. Pirkle and P. E. Adams, J. Org. Chem., 45, 4111 (1980). 